\title{
Bisphenol A and S impaired ovine granulosa cell steroidogenesis
}

\author{
Ophélie Téteau,*, Manon Jaubert1,*, Alice Desmarchais, Pascal Papillier ${ }^{1}$, Aurélien Binet ${ }^{1,2}$, \\ Virginie Maillard ${ }^{1}$ and Sébastien Elis ${ }^{1}$ \\ ${ }^{1} P R C$, INRAE, CNRS, Université de Tours, IFCE, Nouzilly, France and ${ }^{2}$ Service de Chirurgie pédiatrique viscérale, \\ urologique, plastique et brûlés, Tours, France
}

Correspondence should be addressed to S Elis; Email: sebastien.elis@inrae.fr

*(O Téteau and M Jaubert contributed equally to this work)

\begin{abstract}
Bisphenols, plasticisers used in food containers, can transfer to food. Bisphenol A (BPA) has been described as an endocrine disruptor and consequently banned from the food industry in several countries. It was replaced by a structural analogue, Bisphenol S (BPS). BPA action on the steroidogenesis is one of the mechanisms underlying its adverse effects on the efficiency of female reproduction. This study aimed to determine whether BPS is a safe alternative to BPA regarding GC functions. Antral follicles (2-6 mm), of approximatively 1000 adult ewe ovaries, were aspired and GC purified. For 48 h, ovine GC were treated with BPA or BPS (from 1 nM to $200 \mu \mathrm{M})$ and the effects on cell viability, proliferation, steroid production, steroidogenic enzyme expression and signalling pathways were investigated. Dosages at and greater than $100 \mu \mathrm{M}$ BPA and $10 \mu \mathrm{M}$ BPS decreased progesterone secretion by $39 \%$ $(P<0.001)$ and $22 \%(P=0.040)$, respectively. BPA and BPS $10 \mu \mathrm{M}$ and previously mentioned concentrations increased oestradiol secretion two-fold $(P<0.001$ and $P=0.082$, respectively). Only $100 \mu \mathrm{M} B P A$ induced a decrease $(P<0.001)$ in gene expression of the enzymes of steroidogenesis involved in the production of progesterone. BPA reduced MAPK3/1 phosphorylation and ESR1 and ESR2 gene expression, effects that were not observed with BPS. BPA and BPS altered steroidogenesis of ovine GC. Thus, BPS does not appear to be a safe alternative for BPA. Further investigations are required to elucidate BPA and BPS mechanisms of action. Reproduction (2020) 159 571-583
\end{abstract}

\section{Introduction}

The ovarian follicle is composed of an oocyte; it includes granulosa cells (GC) that border the antrum and is filled with follicular fluid. GC have two essential functions: cell proliferation and steroidogenesis. Due to their secretory function, these cells play a fundamental role in oocyte growth and maturation (Monniaux et al. 2019). Nevertheless, these cells can be affected by environmental factors such as diets or pollutants (Hernandez-Medrano et al. 2012, Bloom et al. 2016).

Bisphenol A (BPA) has been used in the plastic industry since 1940 (Usman \& Ahmad 2016). It is found in food containers, water pipes, cosmetics, dental sealants and medical equipment (Vandenberg et al. 2007). Bisphenols can transfer from container to content even under normal conditions of use and therefore contaminate food, the main source of exposure (Vandenberg et al. 2007, Wu et al. 2018b). BPA is found in many human tissues and fluids: breast milk and colostrum ( 3 and 15 $\mathrm{nM}$, respectively), amniotic fluid (4-39 nM), placental tissue $(11.2 \mathrm{ng} / \mathrm{g})$, blood $(0.9-90 \mathrm{nM})$, urine $(11 \mathrm{nM})$ and follicular fluid (9 nM) (Vandenberg et al. 2007).
BPA exhibits adverse effects on human health. Indeed, high BPA levels have been associated with obesity, type 2 diabetes, cardiovascular diseases, disruption of bone metabolism and alterations in both male and female reproductive functions (Ma et al. 2019). BPA shares part of its structure (phenol ring) with that of the hormone $17 \beta$-oestradiol and exhibits moderate oestrogenic activity, despite a 10,000-fold lower binding affinity to oestrogen receptors (ER) $\alpha$ (ESR1) and ER $\beta$ (ESR2) compared to oestradiol (Grignard et al. 2012, MolinaMolina et al. 2013). Previous studies demonstrated that BPA alters ER $\alpha$ and ER $\beta$ expression in rats (TomzaMarciniak et al. 2018). Moreover, the interference of BPA on GC steroidogenesis is one of the mechanisms that explain the negative impact of BPA on reproduction (Bloom et al. 2016). In porcine and luteinised human GC, $100 \mu \mathrm{M}$ BPA decreases oestradiol and progesterone secretion, after $48 \mathrm{~h}$ or $72 \mathrm{~h}$ of culture, an effect that is associated with reduced steroidogenic enzyme (STAR, CYP19A1, CYP11A1 and HSD3B1) expression (Mlynarcikova et al. 2005, Bloom et al. 2016, Mansur et al. 2016, Bujnakova Mlynarcikova et al. 2018, Pogrmic-Majkic et al. 2019). Nevertheless, other studies 
showed an increase in oestradiol secretion with porcine GC with $10 \mu \mathrm{M}$ BPA, after $24 \mathrm{~h}$ or $48 \mathrm{~h}$ of treatment (Wu et al. 2018a, Song et al. 2019). Such modifications in GC steroid production can lead to ovarian dysfunction. Moreover, $100 \mu \mathrm{M}$ BPA exposure for $30 \mathrm{~min}$ increases MAPK3/1 phosphorylation in human GC (PogrmicMajkic et al. 2019); this pathway is a key regulator of cell survival and proliferation (Fan et al. 2009). Furthermore, urine BPA concentration above $1.6 \mu \mathrm{g} / \mathrm{L}(9$ $\mathrm{nM}$ ) in women who are undergoing assisted reproductive technology are potentially associated with a reduced number of pre-ovulatory follicles, compared to women exhibiting <0.4-0.9 $\mu \mathrm{g} / \mathrm{L}$ urine BPA concentration (Souter et al. 2013). BPA has therefore been classified as an endocrine disruptor, and its use has been banned in the food industry in several countries (Canada, Belgium and France) (European-Food-Safety-Authority 2015, Usman \& Ahmad 2016). New BPA structural analogues emerged, particularly Bisphenol S (BPS), which is still unregulated even though it is increasingly present in the environment. Thus, BPS is now found in most urine samples at average concentrations similar to BPA (0.08-84 nM; Wu et al. 2018b). The BPS studies in animal models (zebrafish Danio rerio) and cell lines (mouse 3T3-L1 adipocytes) also report harmful health effects, including obesity and disruption of reproductive functions (Chen et al. 2016). Only a few studies focused on the impact of BPS on mammalian GC. Nevertheless, $100 \mu \mathrm{M}$ BPS increases oestradiol secretion in bovine GC after 6 days of exposure (Campen et al. 2018), and mice injected with BPS $(10 \mathrm{mg} / \mathrm{kg}$ from birth to postnatal days 60 by s.c. injection every three days) exhibit increased serum 17ß-oestradiol (Shi et al. 2017). Conversely, 10 $\mu \mathrm{M}$ BPS decreases oestradiol secretion in porcine GC and cell proliferation (Berni et al. 2019).

The discrepancies among studies may be due to differences in sensitivity between mono- (cow) vs polyovulating species (rodents and pig). Indeed, rodents are less sensitive (100 to 1000-fold) to bisphenol effects on testosterone secretion by testicular foetal cells compared to human cells (Eladak et al. 2015). It is therefore necessary to assess the effects of BPA and BPS in a species relevant to the human female reproduction, as the ewe (Scaramuzzi et al. 2011, Monniaux et al. 2019). Indeed, ewes and humans have ovaries of similar size and shape (Lunardi et al. 2015). They also have similar follicle kinetic (180 days and 200 days from the exit of the follicular reserve to the pre-ovulatory stage for ewe and women, respectively) (Monniaux et al. 2014). Moreover, sheep have already been described as a relevant model for toxicology studies, including BPA studies (Rivera et al. 2011, Corbel et al. 2013, Lunardi et al. 2015, Grandin et al. 2018, Gingrich et al. 2019).

In this study, we investigated whether BPS is a safe alternative to BPA. Indeed, we hypothesized that BPS would have similar deleterious effect as BPA on GC functions, including its steroidogenesis. Our objective was to compare the effects of these two compounds on sheep GC and to study their mechanisms of action. We analysed GC viability and proliferation, secretion of oestradiol and progesterone, expression of steroidogenic enzymes, hormonal receptor gene expression and signalling pathways.

\section{Materials and methods \\ Chemicals and antibodies}

All chemicals were obtained from Sigma-Aldrich, unless otherwise stated in the text. The rabbit polyclonal antibody to human cytochrome P450 family 19 subfamily A member 1 (CYP19A1) and mouse monoclonal antibody to human vinculin and horseradish-peroxidase-conjugated antimouse, anti-rabbit, and anti-goat antibodies were obtained from Sigma-Aldrich. The goat polyclonal antibody to human cytochrome P450 family 11 subfamily A member 1 (CYP11A1) was purchased from Santa Cruz Biotechnology. The rabbit polyclonal antibody to human hydroxyl-delta-5steroid dehydrogenase, 3 beta- and steroid delta-isomerase 1 (HSD3B1) was obtained from Abgent (San Diego, CA, USA). Rabbit polyclonal antibodies to human protein kinase B (Akt), 5' AMP-activated protein kinase alpha (AMPK $\alpha$ ), phosphoAMPK $\alpha$ (Thr172), p44/42 mitogen-activated protein kinase 3/1 (MAPK3/1) and rabbit monoclonal antibodies to human phospho-Akt (Ser473), phospho-p44/42 MAPK (MAPK3/1; Thr202/Tyr204), p38 MAPK (MAPK14) and phospho-p38 MAPK (MAPK14, Thr180/Tyr182) were purchased from Cell signalling Technology. Ethanol was used as a solvent for BPA and BPS at concentrations that do not negatively impact the cells. Absence of ethanol effect on GC viability and progesterone secretion was confirmed for all ethanol concentrations used, ranging from $1 / 100,000,000$ to $1 / 500$ (corresponding to the BP concentrations used, ranging from $1 \mathrm{nM}$ to $200 \mu \mathrm{M}$ ) (Supplementary Fig. 1, see section on supplementary materials given at the end of this article).

\section{Isolation and culture of GC}

Approximately 1000 ovaries of adult ewes were collected from local slaughterhouses to perform the experiments described in this paper. Antral follicles ( 2 to $6 \mathrm{~mm}$ ) were punctured with an 20G needle connected to a vacuum pump and a collection tube to receive follicular fluid that contained cumulusoocyte complex (COC) and GC. COC were removed under binocular observation. Negligible presence of cumulus cells (CC) compared to GC was confirmed by measuring expression of CC and GC specific genes by qPCR (Supplementary Fig. 2). GC were washed in complemented serum-free McCoy's 5A medium: $3 \mathrm{mM}$ L-glutamine, 0.1\% BSA (Cell Signalling Technology), 100,000 UI/L penicillin, $100 \mathrm{mg} / \mathrm{L}$ streptomycin, $20 \mathrm{mM}$ HEPES (pH 7.6), $100 \mathrm{nM}$ 4-androsten-11 $\beta$-ol-3,17dione, $5 \mathrm{mg} / \mathrm{L}$ bovine apo-transferrin, $250 \mathrm{nM}$ selenium and $1.72 \mathrm{nM}$ insulin. After centrifugation and washing in medium, GC were purified with a Percoll gradient $(50 \%$ Percoll and 50\% medium). Recovered cells were counted in a haemocytometer. GC were plated overnight in 96-well 
plates (Thermo Scientific Biolite) at $1 \times 10^{5}$ viable cells/150 $\mu \mathrm{L}$ medium/well in complemented serum-free McCoy's $5 \mathrm{~A}$ medium. Then, GC were cultured for $48 \mathrm{~h}$ in the presence or absence (control) of BPA or BPS at eight concentrations: $1 \mathrm{nM}$, $10 \mathrm{nM}, 100 \mathrm{nM}, 1 \mu \mathrm{M}, 10 \mu \mathrm{M}, 50 \mu \mathrm{M}, 100 \mu \mathrm{M}$ or $200 \mu \mathrm{M}$. This concentration range extends from doses found in human biological fluids during chronic exposure (Vandenberg et al. 2007), including people exposed professionally (Hines et al. 2017), to the supraenvironmental dose of $200 \mu \mathrm{M}$. Cultures were performed at $38.5^{\circ} \mathrm{C}$ in a humidified atmosphere that contained $5 \% \mathrm{CO}_{2}$ and $20 \% \mathrm{O}_{2}$ in air. There was no foetal bovine serum in medium, and the relatively short culture time was chosen in order to limit GC differentiation and retain the round shape. GC were still able to proliferate and exhibit steroidogenic activity. For the assessment of cell proliferation and steroid secretion, a positive control was carried out during cell cultures (10 nM Insulin Growth Factor-1), as well as a negative control for the measurement of cell viability $(1 \%$ saponin and $70 \%$ methanol).

\section{Cell viability}

After a 48-h treatment in the presence or absence of BPA or BPS $(10 \mu \mathrm{M}, 50 \mu \mathrm{M}, 100 \mu \mathrm{M}$ or $200 \mu \mathrm{M}$, doses impacting cell proliferation and steroidogenesis), cell viability was determined according to two complementary methods: Live/ Dead staining and spent media adenylate kinase activity assay. Concerning Live/Dead staining, GC $\left(250 \times 10^{3}\right.$ viable cells/250 $\mu \mathrm{L}$ media/well) were cultured in an eight-chamber slide in complemented serum-free McCoy's 5A media. Live/ Dead staining was applied (green fluorescence corresponds to living cells and red fluorescence corresponds to dead cells) according to the manufacturer's instructions (Thermo Fisher Scientific). The number of living and dead cells was counted in four fields/chamber (an average of 800 cells per field was counted) using ImageJ software (ImageJ-win64). The results are expressed as percentage of dead cells of three independent cultures. For the adenylate kinase assay, GC $\left(1 \times 10^{5}\right.$ viable cells/100 $\mu \mathrm{L}$ medium/well) were cultured in 96-well dishes in complemented serum-free McCoy's 5A media. After a 48-h treatment, the activity of adenylate kinase released into the culture supernatant by dead cells was assessed by bioluminescence according to the manufacturer's instructions (MBL International Corporation, Nanterre, France). The results are expressed as the mean \pm S.E.M. of six independent cultures and normalised to the mean of the control condition.

\section{Cell proliferation}

GC $\left(1 \times 10^{5}\right.$ viable cells/150 $\mu \mathrm{L}$ medium/well $)$ were cultured in 96-well plates in complemented serum-free McCoy's 5A medium. After a 48-h treatment with $10 \mu \mathrm{M}$ bromodeoxyuridine/5-bromo-2'-deoxyuridine (BrdU) in the presence or absence of BPA or BPS (1 nM, $10 \mathrm{nM}, 100 \mathrm{nM}$, $1 \mu \mathrm{M}, 10 \mu \mathrm{M}, 50 \mu \mathrm{M}, 100 \mu \mathrm{M}$ or $200 \mu \mathrm{M})$, the supernatants were removed. Cell proliferation was measured with an enzyme immunoassay according to the manufacturer's instructions (Cell Proliferation ELISA, BrdU (colourimetric), Roche Applied Science, Germany). The results are expressed as the mean \pm S.E.M. of 13 independent cultures, with each condition performed in duplicate and normalised to the control condition.

\section{Progesterone assay}

GC $\left(1 \times 10^{5}\right.$ viable cells/150 $\mu \mathrm{L}$ medium/well $)$ were cultured in 96-well dishes in complemented serum-free McCoy's 5A medium. After 48-h treatment in the presence or absence of BPA or BPS (1 nM, $10 \mathrm{nM}, 100 \mathrm{nM}, 1 \mu \mathrm{M}, 10 \mu \mathrm{M}, 50 \mu \mathrm{M}, 100$ $\mu \mathrm{M}$ or $200 \mu \mathrm{M})$, the supernatants were collected to measure the progesterone and oestradiol secretion. The progesterone concentration was measured using an enzyme immunoassay protocol, as described previously (Canépa et al. 2008). The cell layers were used to quantify the proteins in each corresponding well (BCA protein quantification kit; Interchim, Montluçon, France). For progesterone concentrations that ranged from 0.2 to $10 \mathrm{ng} / \mathrm{mL}$, the intra-assay coefficient of variation $(\mathrm{CVs})$ averaged less than $10 \%$. Progesterone concentration was normalised by the protein concentration of each well. The results are expressed as the amount of progesterone $(\mathrm{ng} / \mathrm{mL})$ secreted per $48 \mathrm{~h}$ per protein amount $(\mu \mathrm{g} / \mathrm{mL})$ per well as the mean \pm S.E.M. of 12 independent cultures, with each condition performed in duplicate and normalised to the control condition.

\section{Oestradiol assay}

The oestradiol concentration was measured using an enzyme immunoassay (E2-EASIA-kit, DIAsource, LouvainLan-Neuve, Belgium), according to the manufacturer's instructions. Cell layers were used to quantify the proteins in each corresponding well (BCA protein quantification kit). For oestradiol concentrations that ranged from 1.56 to 50 $\mathrm{pg} / \mathrm{mL}$, the intra-assay $\mathrm{CVs}$ averaged $15 \%$. The oestradiol concentration was normalised by the protein concentration of each well. The results are expressed as the amount of oestradiol $(\mathrm{pg} / \mathrm{mL})$ secreted per $48 \mathrm{~h}$ per protein amount $(\mu \mathrm{g} /$ $\mathrm{mL}$ ) per well as mean \pm s.E.M. of five independent cultures, with each condition performed in duplicate and normalised to the control condition.

\section{Protein extraction and immunoblotting}

GC were cultured in 96 -well plates $\left(1 \times 10^{5}\right.$ viable cells/150 $\mu \mathrm{L}$ medium/well) in complemented serum-free McCoy's $5 \mathrm{~A}$ medium. After a 48-h treatment in presence or absence of 10 $\mu \mathrm{M}$ BPA or BPS (the lowest concentration of BPS affecting GC steroidogenesis), protein was extracted. Twelve micrograms of protein were subjected to Western blotting as previously described (Maillard et al. 2018). The lysates were used to measure steroidogenic enzymes (CYP19A1, CYP11A1 and HSD3B1) and cell signalling pathway proteins (Akt, MAPK3/1, AMPK $\alpha$ and MAPK14). The blots were incubated overnight at $4{ }^{\circ} \mathrm{C}$ with appropriate primary antibodies (Table 1) in Trisbuffered saline with $0.1 \%$ Tween 20 (TBST) with 5\% non-fat dry milk powder (NFDMP). After several washes in TBST, the membranes were incubated for $90 \mathrm{~min}$ at room temperature with horseradish-peroxidase-conjugated secondary anti-rabbit, 
Table 1 Antibodies used in this study.

\begin{tabular}{|c|c|c|c|c|}
\hline Protein & Source & Primary Ab dilutions & Secondary Ab dilutions & Molecular weight $(\mathrm{kDa})$ \\
\hline Vinculin & Mouse & $1 / 1000$ & $1 / 7000$ & 117 \\
\hline CYP19A1 & Rabbit & $1 / 500$ & $1 / 5000$ & 58 \\
\hline CYP11A1 & Goat & $1 / 500$ & $1 / 5000$ & 55 \\
\hline HSD3B1 & Rabbit & $1 / 500$ & $1 / 5000$ & 42 \\
\hline p-Akt (Ser473) & Rabbit & $1 / 2000$ & $1 / 5000$ & 60 \\
\hline Akt & Rabbit & $1 / 1000$ & $1 / 5000$ & 60 \\
\hline p-AMPK $\alpha(T h r 172)$ & Rabbit & $1 / 1000$ & $1 / 5000$ & 62 \\
\hline AMPK $\alpha$ & Rabbit & $1 / 1000$ & $1 / 5000$ & 62 \\
\hline p-p44-42 MAPK (Erk1/2) (Thr202/Tyr204) & Rabbit & $1 / 2000$ & $1 / 5000$ & $42-44$ \\
\hline p44/42 MAPK (Erk1/2) & Rabbit & $1 / 1000$ & $1 / 5000$ & $42-44$ \\
\hline p-p38 MAPK (Thr180/Tyr182) & Rabbit & $1 / 1000$ & $1 / 5000$ & 40 \\
\hline p38 MAPK & Rabbit & $1 / 1000$ & $1 / 5000$ & 40 \\
\hline
\end{tabular}

anti-goat or anti-mouse IgG (according to primary antibody; Table 1) in TBST with 5\% NFDMP. After washing again in TBST, the signal of specific bands was visualised by ECL (West Dura; Thermo-Fisher Scientific) and quantified using a GeneGnome charge-coupled device camera (Syngene, Cambridge, United Kingdom) and Genesys 1.5.5 software (Syngene). Signal intensity was analysed using GeneTools 4.01 software (Syngene). For steroidogenic enzymes, protein expression is reported relative to the expression of vinculin (a housekeeping protein) and normalised to the control condition. The results of cell signalling pathway proteins are expressed as the ratio of phosphorylated protein to total protein, normalised to the control before treatment. Protein lysates from six independent cultures were used for each protein.

\section{RNA extraction, real-time polymerase chain reaction $(q P C R)$ and gene expression}

GC were cultured in 96 -well plates $\left(1 \times 10^{5}\right.$ viable cells/150 $\mu \mathrm{L}$ medium/well) in complemented serum-free McCoy's $5 \mathrm{~A}$ medium. After a 48-h treatment in presence or absence of BPA or BPS (10 nM, $100 \mathrm{nM}, 1 \mu \mathrm{M}, 10 \mu \mathrm{M}, 50 \mu \mathrm{M}$ or $100 \mu \mathrm{M})$, cells were collected and mRNA was extracted. DNase treatment was performed with NucleoSpin ${ }^{\circledR}$ RNA kit (MachereyNagel, Hoerdt, France), according to the manufacturer's recommendations. The quantity and quality of RNA was assessed with a Nanodrop ND-1000 Spectrophotometer (Nyxor biotech, Paris, France). RT was performed on 500 ng of total RNA extracted with Maxima Strand cDNA Synthesis Kit (Thermo-Fisher Scientific), according to the manufacturer's instructions. qPCR reactions for androgen receptor $(A R)$, progesterone receptor $(P R)$, oestrogen receptor 1 (ESR1), ESR2, CYP19A1, CYP11A1, HSD3B1 and StAR protein (STAR) gene expression were performed. qPCR were carried out with specific primers pairs (Table 2; at a final concentration of 125 nM of each), RT reaction (diluted 1/150) and qPCR Mastermix Plus for Sybr Green I (Bio Rad), according to the manufacturer's instructions, on a CFX96 (Bio Rad), and analysed as previously described (Maillard et al. 2018). The efficiency of the primers (Table 2) and standard curve were determined for each gene. Relative gene expression levels were calculated. The geometric mean of two housekeeping genes (ribosomal protein L19
(RPL19) and beta-actin (ACTB)) was used to normalise gene expression. The relative amounts of gene transcripts (R) were calculated with six independent cultures using the following equation:

$$
R=\frac{\left(E_{\text {gene }}^{-C t \text { gene }}\right)}{\left(\text { geometric mean }\left(E_{\text {ACTINE } \beta}^{-C t \text { ACTINE } \beta} ; E_{R P L 19}^{-C t R P L 19}\right)\right)}
$$

where Ct corresponds to the cycle threshold and $E$ indicates the PCR efficiency for each primer pair.

\section{Statistical analysis}

Statistical analyses were performend with $\mathrm{R}$ version 3.5.1 using the $\mathrm{R}$ Commander package. All results, except for viability experiments with Live/Dead staining, are presented as the mean \pm S.E.M., and non-parametric permutation ANOVA ( $R$ package Imperm) was performed. Thus, treatment effect, culture effect and treatment-by-culture interactions were assessed. When the treatment condition was significant, the Tukey post hoc test ( $\mathrm{R}$ package nparcomp) was executed. Regarding viability experiments with Live/Dead staining, a logistic regression analysis was used, and data are presented as percentage \pm S.E.M. Differences were considered significant when $P$ value was $<0.05$ and as a tendency when $0.05<P<0.1$.

\section{Results}

\section{Effects of BPA and BPS on ovine GC viability}

The effects of BPA and BPS $(10 \mu \mathrm{M}, 50 \mu \mathrm{M}, 100 \mu \mathrm{M}$ or $200 \mu \mathrm{M}$ ) on cell viability after 48 -h treatment were determined according to two complementary methods (Fig. 1): Live/Dead staining (Fig. 1A) and adenylate kinase activity assay in the medium (Fig. 1B). No BPS treatment affected cell viability compared to control. Only the highest BPA concentration $(200 \mu \mathrm{M})$ increased cell mortality: $99.5 \%$ compared to $42.7 \%$ in control $(P<0.001$; Fig. 1A). This result was confirmed with adenylate kinase activity assay. Indeed, $200 \mu \mathrm{M}$ BPA induced a 1.8-fold increase in mortality compared to control $(P<0.001$; Fig. 1B). 


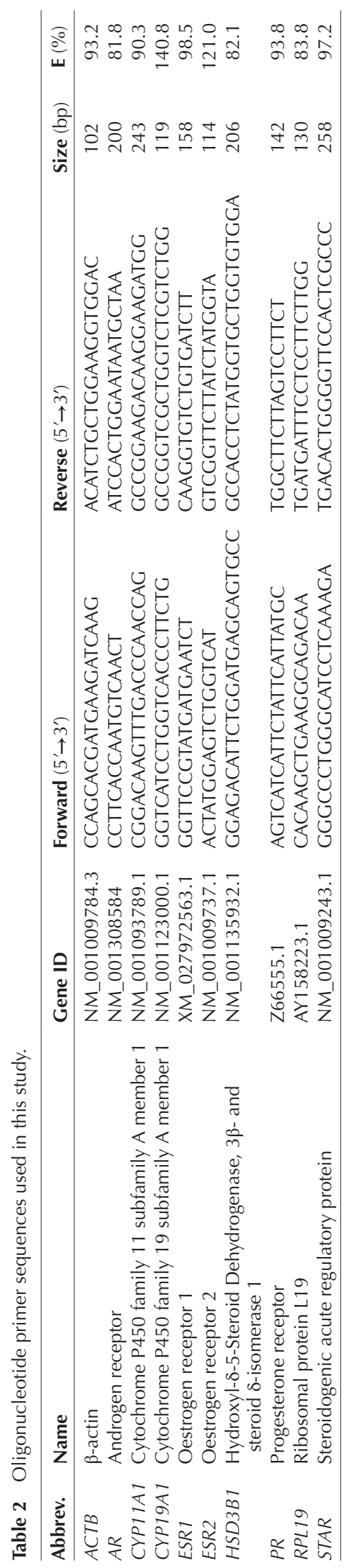

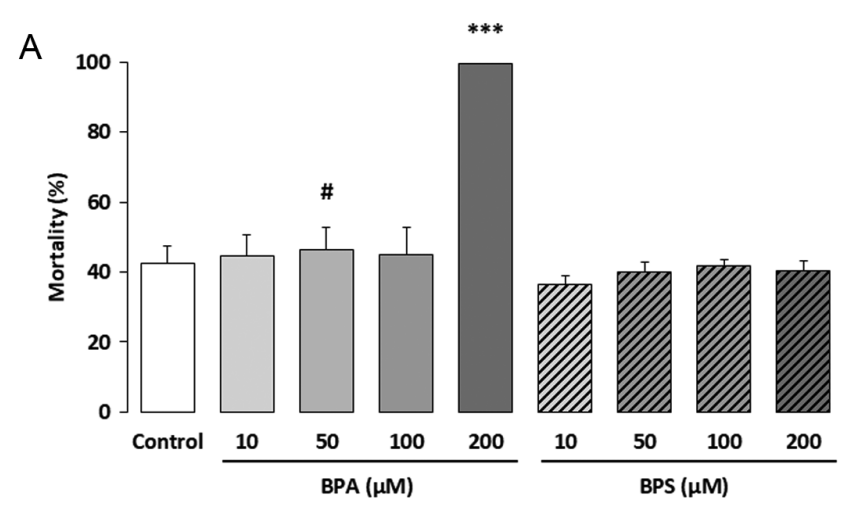

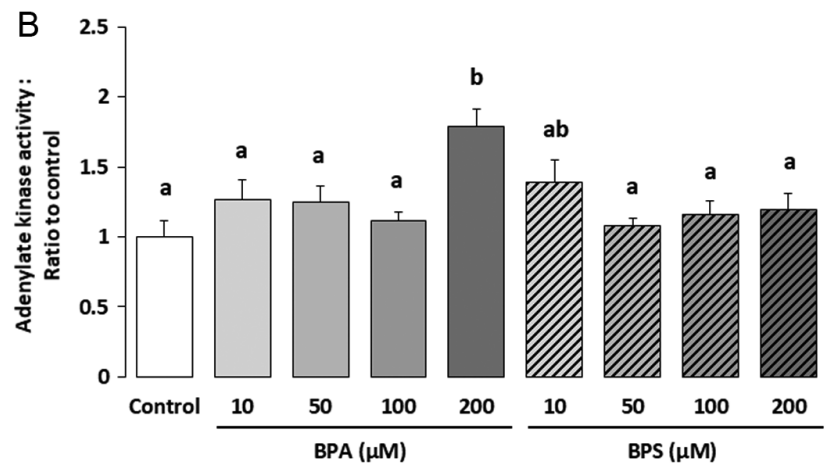

Figure 1 Effects of bisphenol A or S (BPA or BPS) on cell viability. Cell viability was assessed in ovine granulosa cells (GC) after 48-h treatment in the presence or absence of BPA or BPS $(10,50,100$ or $200 \mu \mathrm{M})$ according to two complementary methods. Live/Dead staining (A) was performed according to the manufacturer's instructions; green fluorescence corresponds to living cells and red fluorescence corresponds to dead cells. The results are expressed as the percentage of dead cells from three independent cultures.

*** indicates a significant difference $(P<0.001)$ and \# indicates a tendency $(0.05<P<0.1)$. The activity of adenylate kinase (B) released into the culture supernatant by dead cells was assessed by bioluminescence (according to the manufacturer's instructions). The results are expressed as the mean \pm S.E.M. of six independent cultures and normalised to the mean of control condition. Bars that do not exhibit at least one common letter are significantly different $(P<0.05)$.

\section{Effects of BPA and BPS on ovine GC proliferation}

The proliferation of ovine GC in the presence or absence of BPA or BPS ( $1 \mathrm{nM}, 10 \mathrm{nM}, 100 \mathrm{nM}, 1 \mu \mathrm{M}$, $10 \mu \mathrm{M}, 50 \mu \mathrm{M}, 100 \mu \mathrm{M}$ or $200 \mu \mathrm{M}$ ) was assessed by the incorporation of BrdU after 48-h treatment (Fig. 2). BPA significantly reduced $(P<0.001)$ cell proliferation by $6 \%, 20 \%$ and $72 \%$ at $50 \mu \mathrm{M}, 100 \mu \mathrm{M}$ and $200 \mu \mathrm{M}$, respectively, compared to control (Fig. 2A). While only $200 \mu$ M BPS decreased $(P<0.001)$ GC proliferation by $8 \%$, compared to control (Fig. 2B).

\section{Effects of BPA and BPS on ovine GC progesterone secretion}

Progesterone secretion was measured in spent culture media after 48-h treatment with BPA or BPS (Fig. 3). 

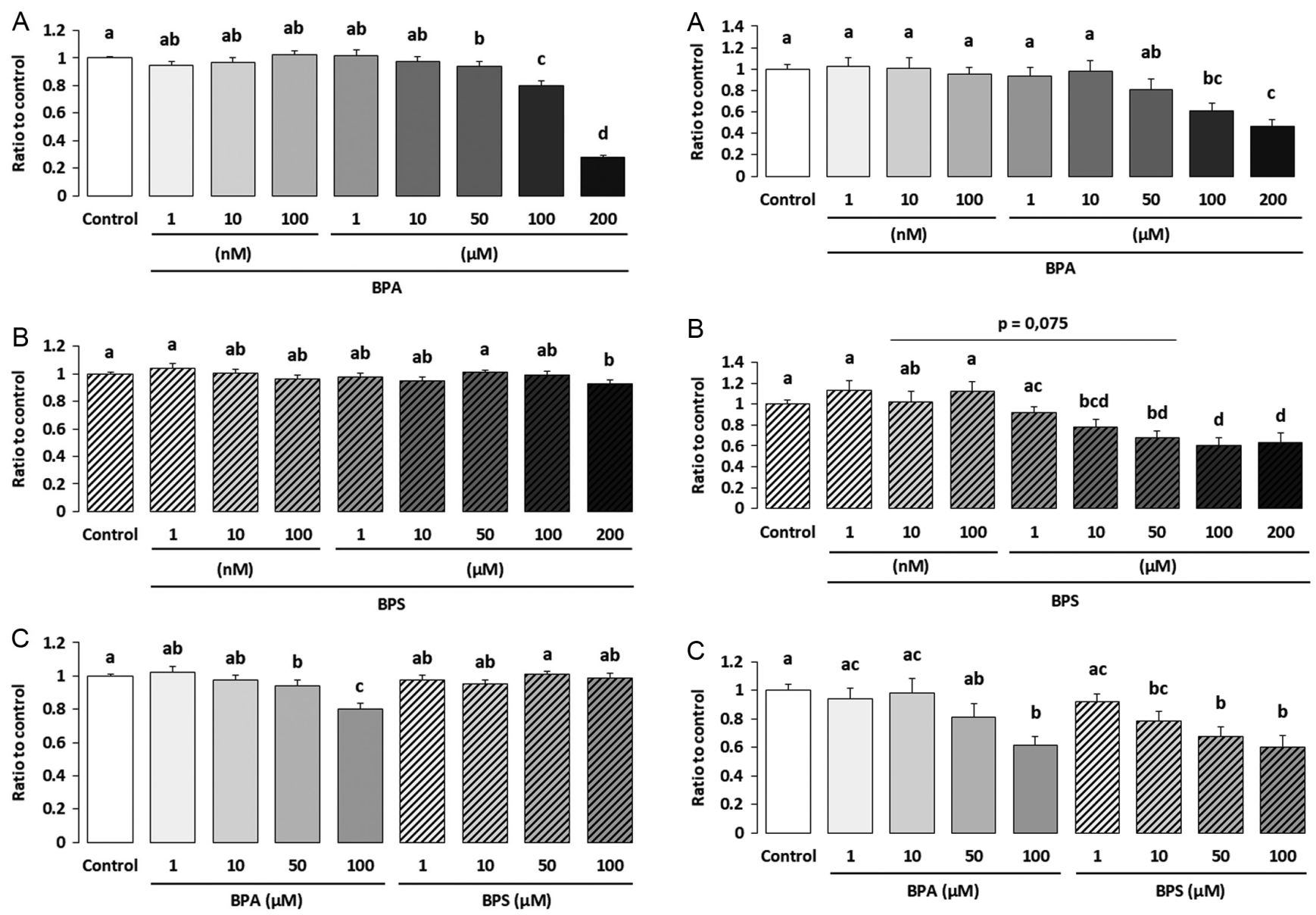

Figure 2 Effects of Bisphenol A or S (BPA or BPS) on cell proliferation. Cell proliferation was assessed in ovine granulosa cells (GC) by bromodeoxyuridine/5-bromo-2'-deoxyuridine (BrdU) incorporation after 48-h culture in complemented serum-free McCoy's 5A media in the presence or absence of various doses of BPA (A) or BPS (B) (1 nM, $10 \mathrm{nM}, 100 \mathrm{nM}, 1 \mu \mathrm{M}, 10 \mu \mathrm{M}, 50 \mu \mathrm{M}, 100 \mu \mathrm{M}$ or $200 \mu \mathrm{M})$. Data with BPA and BPS were compared statistically for four relevant concentrations (C) $(1 \mu \mathrm{M}, 10 \mu \mathrm{M}, 50 \mu \mathrm{M}$ and $100 \mu \mathrm{M})$. The results are expressed as the mean \pm S.E.M. of 13 independent cultures, with each condition in duplicate, and normalised to the control condition of each lot. Bars that do not exhibit at least one common letter are significantly different $(P<0.05)$.

Only $100 \mu \mathrm{M}$ and $200 \mu \mathrm{M}$ BPA decreased $(P<0.001)$ progesterone secretion by $39 \%$ and $54 \%$, respectively $(19.09 \pm 2.62$ and $13.12 \pm 1.76$ ng progesterone/mg protein, respectively), compared to control $(36.23 \pm 3.88$ ng progesterone/mg protein) (Fig. 3A). Interestingly, 10 $\mu \mathrm{M}(P=0.038), 50 \mu \mathrm{M}(P<0.001), 100 \mu \mathrm{M}(P<0.001)$ and $200 \mu \mathrm{M}$ BPS $(P<0.001)$ decreased progesterone secretion by $22 \%, 32 \%$ and $40 \%$, respectively $(28.91 \pm 3.78,22.31 \pm 2.50,17.13 \pm 1.92$ and $16.53 \pm 1.7$ ng progesterone/mg protein, respectively), compared to control (Fig. 3B). Comparatively, $10 \mu \mathrm{M}$ and $50 \mu \mathrm{M}$ BPA did not significantly affect progesterone secretion $(36.08 \pm 5.84$ and $24,03 \pm 3.02 \mathrm{ng}$ progesterone/mg protein, respectively) (Fig. 3C).

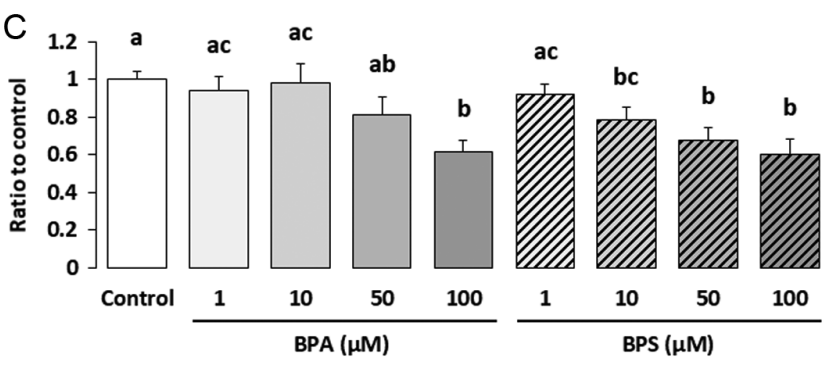

Figure 3 Effects of Bisphenol A or S (BPA or BPS) on progesterone secretion. Progesterone secretion was assessed in ovine granulosa cells (GC). The progesterone concentration was determined in culture medium after 48-h culture in complemented serum-free McCoy's 5A media in the presence or absence of BPA (A) or BPS (B) (1 nM, 10 $\mathrm{nM}, 100 \mathrm{nM}, 1 \mu \mathrm{M}, 10 \mu \mathrm{M}, 50 \mu \mathrm{M}, 100 \mu \mathrm{M}$ or $200 \mu \mathrm{M})$. Data with BPA and BPS were compared statistically for four relevant concentrations (C) $(1 \mu \mathrm{M}, 10 \mu \mathrm{M}, 50 \mu \mathrm{M}$ and $100 \mu \mathrm{M})$. The results are expressed as the mean \pm S.E.M. of 12 independent cultures, with each condition performed in duplicate, and normalised to the control condition of each culture experiment. Bars that do not exhibit at least one common letter are significantly different $(P<0.05)$. The actual control value was $36.23 \pm 3.88$ ng progesterone/mg protein.

\section{Effects of BPA and BPS on oestradiol secretion}

Oestradiol secretion was measured in spent culture media after 48-h treatment with BPA or BPS (Fig. 4). Oestradiol secretion was more than two-fold increased by $10 \mu \mathrm{M}$ BPA $(P<0.001,76.80 \pm 14.96$ pg oestradiol/ $\mathrm{mg}$ protein; Fig. $4 \mathrm{~A})$ and $10 \mu \mathrm{M}$ BPS $(P=0.007$; $61.97 \pm 11.83 \mathrm{pg}$ oestradiol/mg protein; Fig. 4B) compared to control $(28.94 \pm 6.08 \mathrm{pg}$ oestradiol $/ \mathrm{mg}$ protein). This increase was even greater $(P<0.001)$ with higher bisphenol concentrations: 5.8- and 4.3fold for $100 \mu \mathrm{M}$ BPA and BPS $(106.61 \pm 12.54$ and $78.65 \pm 11.28 \mathrm{pg}$ oestradiol/mg protein, respectively) compared to control (Fig. 4C). 

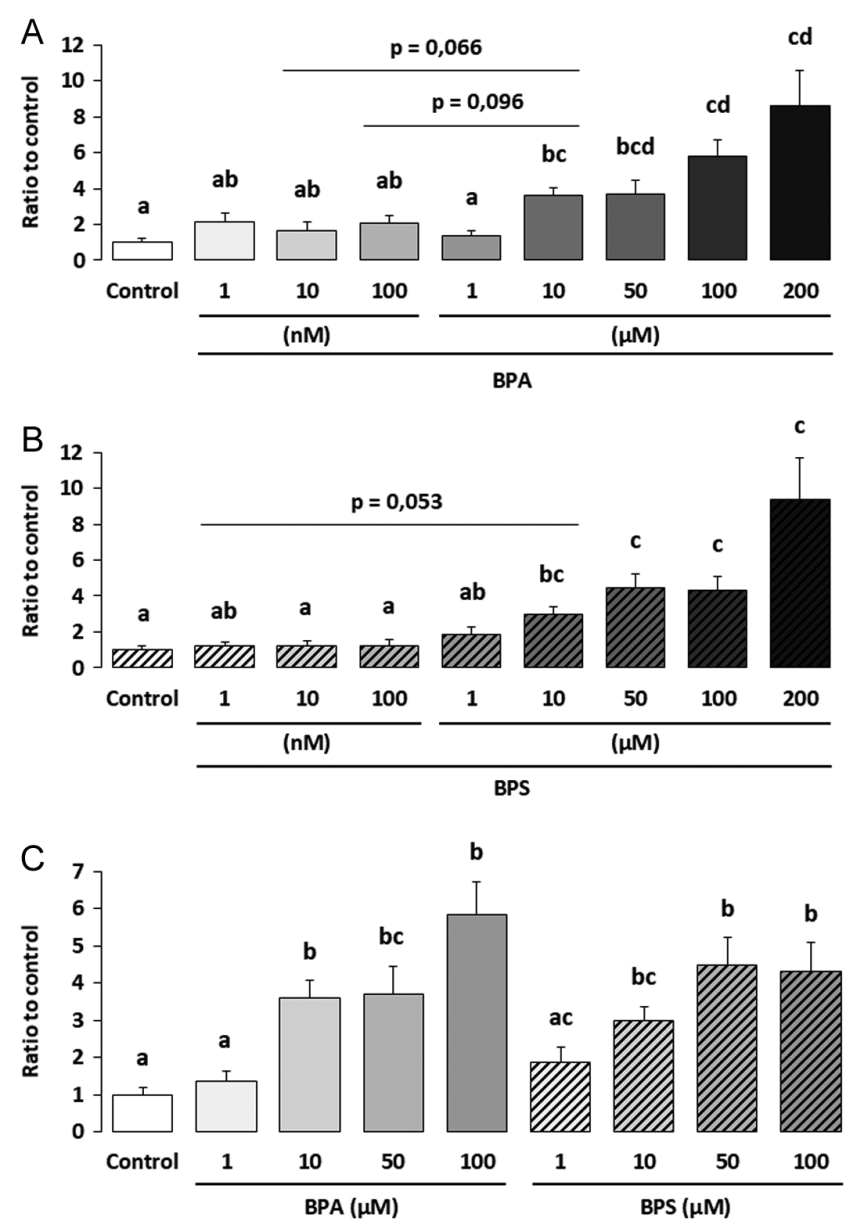

Figure 4 Effects of Bisphenol A or S (BPA or BPS) on oestradiol secretion. Oestradiol secretion were assessed in ovine granulosa cells (GC). The oestradiol concentration was determined in culture medium after 48-h culture in complemented serum-free McCoy's 5A media in presence or absence of BPA (A) or BPS (B) (1 nM, $10 \mathrm{nM}$, $100 \mathrm{nM}, 1 \mu \mathrm{M}, 10 \mu \mathrm{M}, 50 \mu \mathrm{M}, 100 \mu \mathrm{M}$ or $200 \mu \mathrm{M})$. Data with BPA and BPS were compared statistically for four relevant concentrations (C) $(1 \mu \mathrm{M}, 10 \mu \mathrm{M}, 50 \mu \mathrm{M}$ and $100 \mu \mathrm{M})$. The results are expressed as the mean \pm S.E.M. of six independent cultures, with each condition performed in duplicate, and normalised to the control condition of each culture experiment. Bars that do not exhibit at least one common letter are significantly different $(P<0.05)$. The actual control value was $28.94 \pm 6.08 \mathrm{pg}$ oestradiol $/ \mathrm{mg}$ protein.

\section{Effects of BPA and BPS on steroidogenic enzymes protein expression}

The protein expression of three steroidogenic enzymes was measured in ovine GC after 48-h treatment with 10 $\mu \mathrm{M}$ BPA or BPS (Fig. 5). CYP19A1 (Fig. 5A) is involved in oestradiol production, while CYP11A1 (Fig. 5B) and HSD3B1 (Fig. 5C) are involved in progesterone production. There were no statistical differences in protein levels compared to control for any of these steroidogenic enzymes upon BPA or BPS treatment.
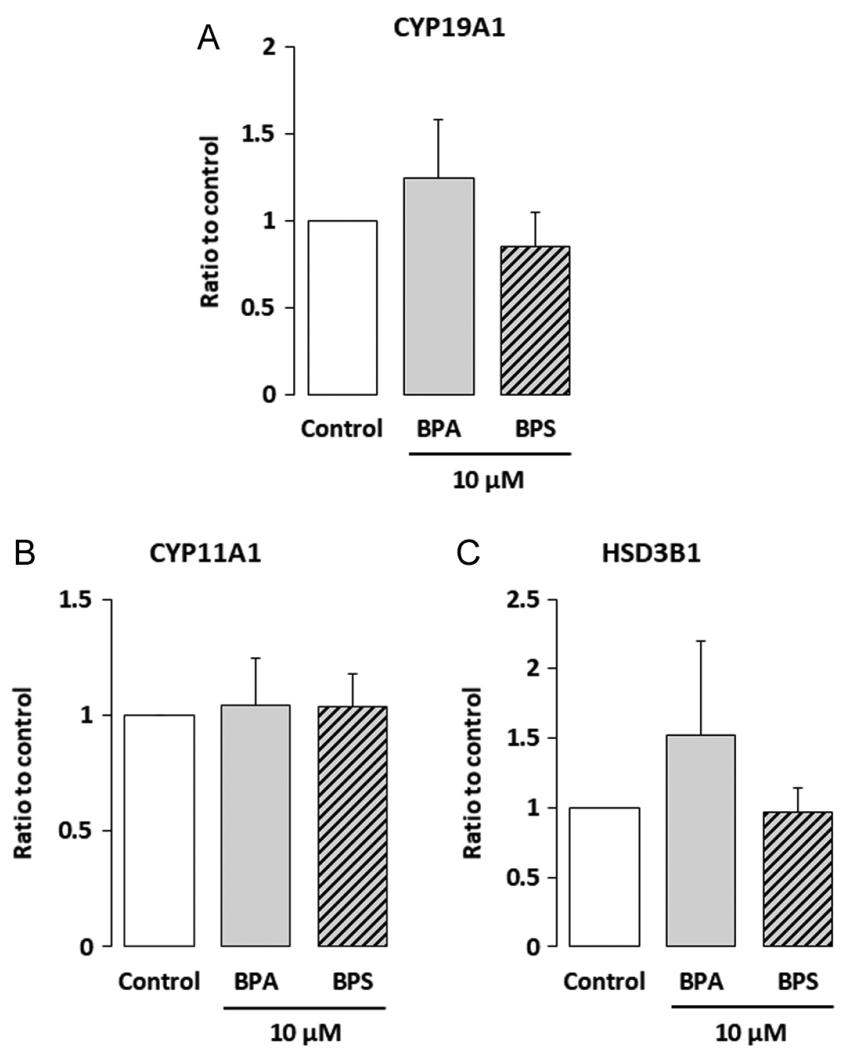

Figure 5 Effects of bisphenol A or S (BPA or BPS) on steroidogenesis enzyme protein expression. The protein expression of three steroidogenesis enzymes, namely cytochrome P450 family 19 subfamily A member 1 (CYP19A1; A), cytochrome P450 family 11 subfamily A member 1 (CYP11A1; B) and hydroxyl-delta-5-steroid dehydrogenase, 3 beta- and steroid delta-isomerase 1 (HSD3B1; C), was assessed in ovine granulosa cells (GC). Protein levels were determined after 48-h culture in complemented serum-free McCoy's $5 \mathrm{~A}$ media in presence or absence of BPA or BPS $(10 \mu \mathrm{M})$. Protein extracts were separated by electrophoresis in a $4-12 \%$ sodium dodecyl sulphate (SDS) polyacrylamide gel. After transfer to nitrocellulose membranes, the proteins were probed with antiCYP19A1 (A), anti-CYP11A1 (B), anti-HSD3B1 (C) or anti-vinculin. Bands on the blots were quantified, and the protein/vinculin ratio was calculated. The results are expressed as the mean \pm S.E.M. of six independent cultures and normalised to the control condition of each culture experiment.

\section{Effects of BPA and BPS on gene expression}

The expression of four hormonal receptor genes $(A R$, $P R, E S R 1$ and ESR2), three steroidogenic enzyme genes (CYP19A1, CYP11A1 and HSD3B1) and the cholesterol transporter gene (STAR) was analysed in ovine GC after 48-h treatment with BPA or BPS (Fig. 6 and Table 3). Only $100 \mu \mathrm{M}$ BPA altered $A R$, namely a $58 \%$ decrease $(P<0.001)$ compared to control. BPS did not affect $A R$ expression (Fig. 6A). $P R$ gene expression did not change significantly compared to control. Nevertheless, there was a two-fold increase $(P=0.003)$ in the expression of this gene with $50 \mu \mathrm{M}$ BPS compared to $50 \mu \mathrm{M}$ BPA. This 


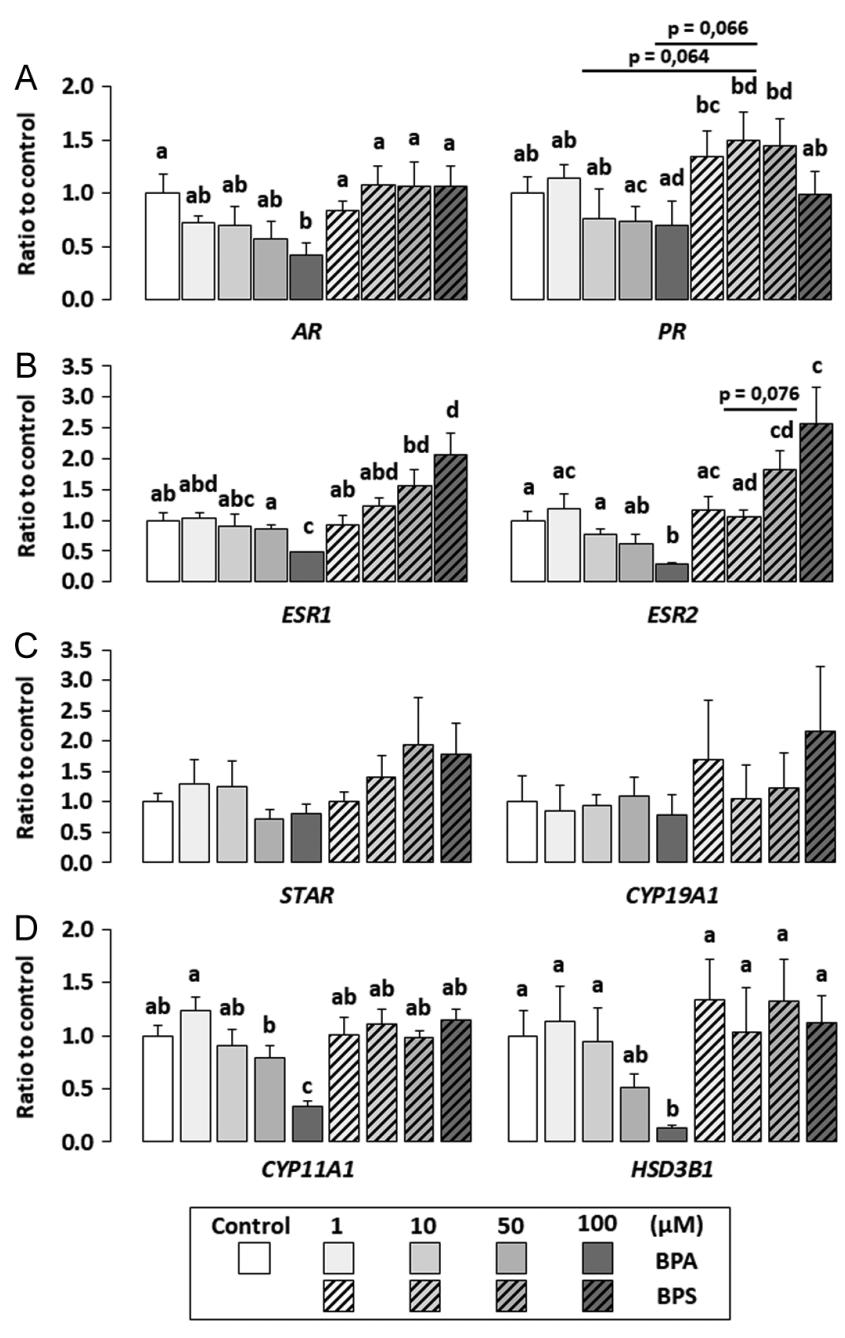

Figure 6 Effects of Bisphenol A or S (BPA or BPS) on gene expression. The gene expression of four hormonal receptors (androgen receptor $(A R)$ and progesterone receptor $(P R) ; \mathrm{A}$, oestrogen receptor 1 (ESR1) and oestrogen receptor $2(E S R 2) ; \mathrm{B})$, the cholesterol transporter (steroidogenic acute regulatory protein $(S T A R) ; \mathrm{C}$ ) and three steroidogenic enzyme (CYP19A1; C, CYP11A1 and HSD3B1; D) were assessed in ovine granulosa cells (GC). Gene expression was determined after 48-h culture in complemented serum-free McCoy's $5 \mathrm{~A}$ media in the presence or absence of BPA or BPS $(1 \mu \mathrm{M}, 10 \mu \mathrm{M}$, $50 \mu \mathrm{M}$ or $100 \mu \mathrm{M}$ ). Total messenger RNA (mRNA) was extracted from GC and reverse transcribed, and real-time polymerase chain reaction (qPCR) was performed. The geometric mean of two housekeeping genes (beta-actin (ACTB) and ribosomal protein L19 (RPL19)) was used to normalise gene expression. The results are expressed as mean \pm S.E.M. of six independent cultures and normalised to the mean of control condition. Bars that do not exhibit at least one common letter are significantly different $(P<0.05)$.

increase occurred as a tendency $(P=0.066)$ between $10 \mu \mathrm{M}$ BPA and BPS (Fig. 6A). Both ESR1 and ESR2 showed a similar gene expression pattern. Indeed, there was a two-fold decrease $(P<0.001)$ in ESR1 and ESR2 expression with $100 \mu \mathrm{M} \mathrm{BPA}$ and a two-fold increase in ESR1 $(P=0.023)$ and ESR2 $(P<0.001)$ for $100 \mu \mathrm{M}$ BPS compared to control. Moreover, this increase in
ESR2 gene expression already occurred with $50 \mu \mathrm{M}$ BPS $(P=0.040)$. Thus, ESR 1 and ESR2 gene expression was increased four- and nine-fold $(P<0.001)$ with $100 \mu \mathrm{M}$ BPS compared to $100 \mu \mathrm{M}$ BPA, respectively. $E S R 1$ and ESR2 gene expression was increased twofold $(P=0.036)$ and three-fold $(P<0.001)$ with $50 \mu \mathrm{M}$ BPS compared to $50 \mu \mathrm{M}$ BPA, respectively (Fig. 6B). Concerning steroidogenic enzyme genes, CYP19A 1 and STAR gene expression did not significantly vary with BPA or BPS (Fig. 6C). Only $100 \mu \mathrm{M}$ BPA caused an effect: a $77 \%$ and $87 \%$ decrease $(P<0.001)$ in CYP11A1 and HSD3B1 expression, respectively, compared to control (Fig. 6D), while none of the BPS concentrations altered steroidogenic gene expression.

\section{Effects of BPA and BPS on signalling pathways}

Signalling pathways involved in GC functions were investigated after $0,5,10,30$ and 60 min treatment in the presence or absence of $10 \mu \mathrm{M}$ BPA or BPS (Fig. 7). Phosphorylation of Akt, MAPK3/1 and MAPK14, all of which are involved in cell viability and proliferation (Peter \& Dhanasekaran 2003, Fan et al. 2009, Lapointe \& Boerboom 2011), and AMPK $\alpha$, which is involved in energetic metabolism including lipid metabolism (Scaramuzzi et al. 2010), was assessed. For the MAPK3/1 pathway, there was a rapid, transient increase $(P<0.001)$ in phosphorylation, reported after $5 \mathrm{~min}$ of treatment with control (three-fold), $10 \mu \mathrm{M}$ BPA (2.5fold) or $10 \mu \mathrm{M}$ BPS (two-fold) compared to control before treatment (Fig. 7A). MAPK3/1 phosphorylation was lower $(P<0.001)$ after 5,10 and $30 \mathrm{~min}$ of 10 $\mu M$ BPA treatment compared with control at the same time. There were no reductions after BPS treatment at any time point. For the AMPK $\alpha$ pathway, there was no change in phosphorylation in the control (Fig. 7B). After 60-min treatment, $10 \mu \mathrm{M}$ BPS increased AMPK $\alpha$ phosphorylation 3.25-fold compared to the control at the same time $(P<0.001)$. Ten micromolar BPA did not alter AMPK $\alpha$ phosphorylation compared to either the control or $10 \mu \mathrm{M}$ BPS. BPS increased $(P<0.001)$ AMPK $\alpha$ phosphorylation at 5, 10, 30 and 60 min (6-, 8.5-, 4.6and 5.2-fold, respectively) compared to control before treatment. Finally, there were no significant differences at any time among control, $10 \mu \mathrm{M} \mathrm{BPA}$ and $10 \mu \mathrm{M}$ BPS in Akt (Fig. 7C) and MAPK14 (Fig. 7D) phosphorylation.

\section{Discussion}

This study aimed to compare the effects of BPA and BPS on ovine GC functions. For the first time, we reported that BPS affected ovine GC steroidogenesis. Concerning progesterone secretion, BPS-induced inhibition occurred at lower concentrations compared to BPA. Moreover, BPS and BPA effects were partially mediated through independent mechanisms because they did not similarly modulate the gene expression of steroidogenic 


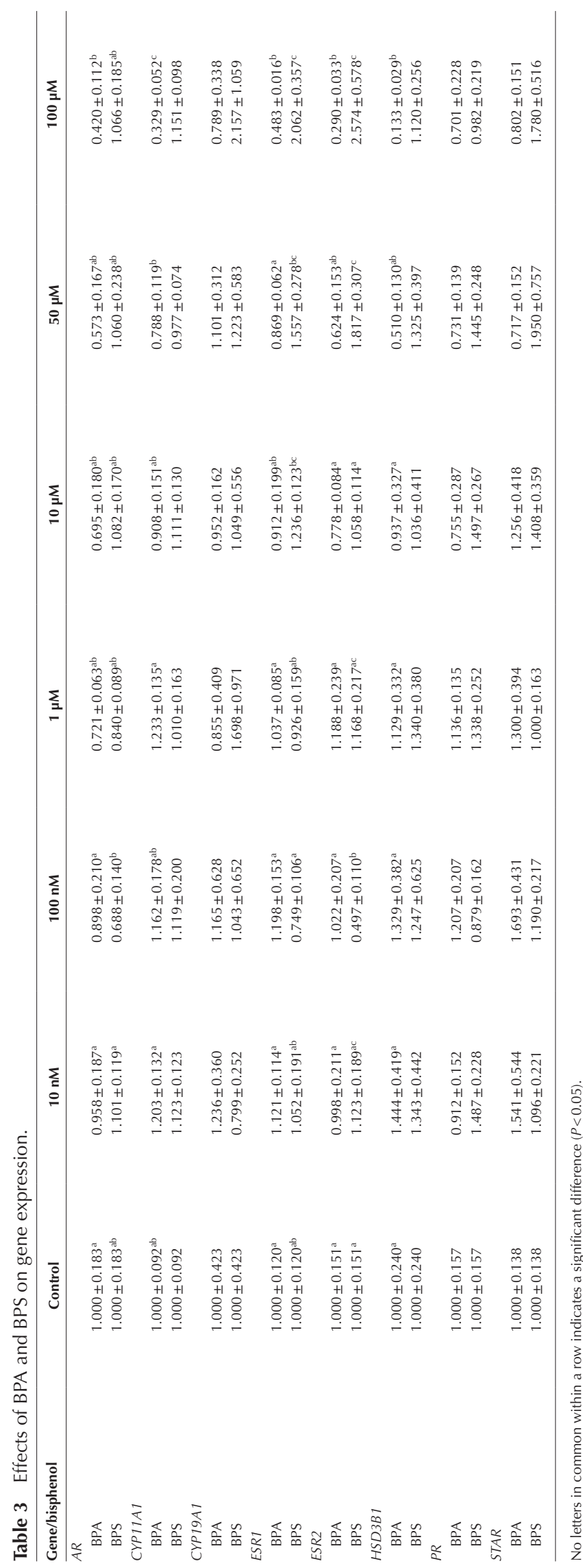

enzymes and hormonal receptors or signalling pathway activation.

\section{BPA and BPS disrupted progesterone and oestradiol secretion}

In this study, we showed that $100 \mu \mathrm{M}$ BPA decreased ovine GC progesterone secretion; this inhibition occurred with a ten-fold lower BPS concentration (10 $\mu \mathrm{M})$. Previous studies also demonstrated a decrease in progesterone secretion in rat GC after $100 \mu \mathrm{M}$ BPA treatment (Samardzija et al. 2018), porcine GC after 100 nM BPA treatment (Grasselli et al. 2010) or luteinised human GC after 8.8 $\mu \mathrm{M}$ BPA treatment (Mansur et al. 2016). Other studies on rat GC (Zhou et al. 2008) and pig GC (Mlynarcikova et al. 2005) showed BPA dosedependently changes progesterone secretion. Indeed, inhibitory effects are reported with high concentrations $(100 \mu \mathrm{M})$, while the opposite effect is observed with low concentrations (100 $\mathrm{nM}$ with rat GC and $10 \mu \mathrm{M}$ with pig GC). BPS reportedly does not affect progesterone secretion at a concentration lower than $100 \mu \mathrm{M}$ in porcine or bovine GC (Campen et al. 2018, Berni et al. 2019). On the contrary, here we reported an inhibitory effect of $10 \mu \mathrm{M}$ BPS on progesterone secretion of ovine GC. In all these models, GC are recovered from similar follicular stages (late maturation but not pre-ovulatory stage), this finding might therefore suggest a higher sensitivity to BPS effects in ovine cells. Nevertheless, differences in culture methods or duration of exposure (up to 6 days) might also explain these differences between species. Intriguingly, neither $P R, S T A R, C Y P 11 A 1, H S D 3 B 1$ gene expression nor CYP11A1, HSD3B1 protein expression were different between control and BPS treated conditions. Further studies are therefore required to elucidate the BPS mechanisms of action impairing progesterone secretion. Progesterone plays a role in the maturation and developmental capacity of the oocyte (Bujnakova Mlynarcikova et al. 2018). In fact, low serum progesterone levels are associated with low ovulation percentages in women (Chou \& Chen 2018). These data therefore suggest that the BPS-induced impairment in progesterone secretion may be detrimental for the oocyte quality and, consequently, fertility.

Regarding oestradiol, we found that both BPA and BPS increased oestradiol secretion in sheep GC at 10 $\mu \mathrm{M}$ or higher. This result is consistent with an in vivo study in mice where injection of BPA or BPS increases serum oestradiol (Shi et al. 2017). Such an increase is also reported in porcine GC after $10 \mu \mathrm{M}$ BPA treatment (Wu et al. 2018a, Song et al. 2019). Nevertheless, in rat and luteinised human GC, BPA treatment (between 10 $\mu \mathrm{M}$ and $100 \mu \mathrm{M}$ ) decreases oestradiol secretion (Zhou et al. 2008, Mansur et al. 2016, Banerjee et al. 2018, Pogrmic-Majkic et al. 2019). There are also discrepancies among species with regards to BPS. Indeed, BPS increases oestradiol secretion in bovine GC at a high 

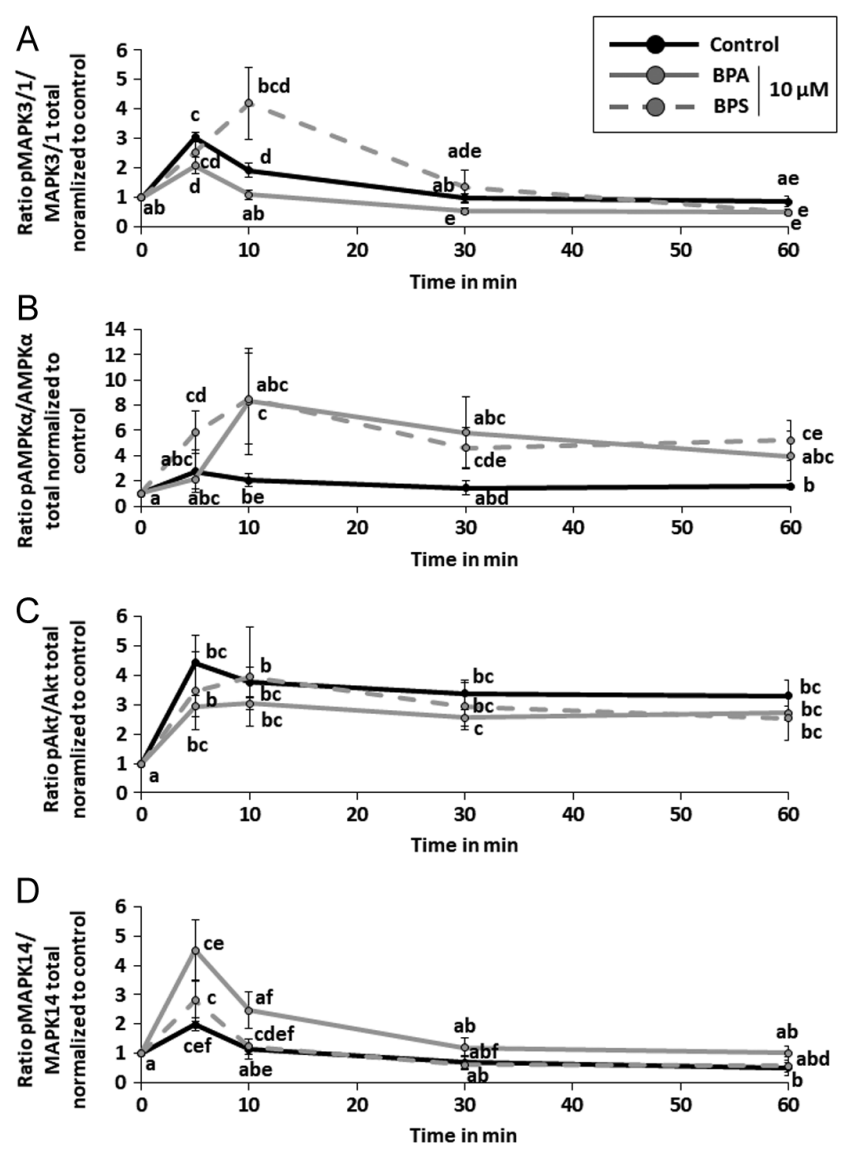

Figure 7 Effects of Bisphenol A or S (BPA or BPS) on protein phosphorylation of signalling pathways. The phosphorylation of signalling pathways proteins, namely mitogen-activated protein kinase 1/3 (MAPK3/1; A), 5' adenosine monophosphate-activated protein kinase (AMPK $\alpha ; B)$, protein kinase $B(A k t ; C)$ and mitogenactivated protein kinase 14 (MAPK14; D) were assessed in ovine granulosa cells (GC). Protein levels were determined after 0, 5, 10, 30 or 60 min culture in complemented serum-free McCoy's 5A media in presence or absence (control) of BPA or BPS $(10 \mu \mathrm{M})$. Protein extracts were separated by electrophoresis in a $4-12 \%$ sodium dodecyl sulphate (SDS) polyacrylamide gel. After transfer to nitrocellulose membranes, the proteins were probed with antiphospho-MAPK3/1 (A) or anti-phospho-AMPK $\alpha$ (B). The blots were stripped and reprobed with antibodies against MAPK3/1 or AMPK $\alpha$, respectively. Bands on the blots were quantified, and the ratio of phosphorylated protein to total protein was calculated. The results are expressed as the mean \pm S.E.M. of four independent cultures and normalised to the control condition before treatment of each culture experiment. No letter in common indicate a significant difference $(P<0.05)$.

concentration (100 $\mu \mathrm{M}$; Campen et al. 2018), while it decreases oestradiol secretion in porcine GC after $1 \mu \mathrm{M}$ BPS treatment (Berni et al. 2019). Oestradiol reportedly exhibits mitogenic and anti-apoptotic effects and is a modulator of the developmental competence of oocytes (Campen et al. 2018, Chou \& Chen 2018). Moreover, the balance between oestradiol and progesterone secretions is crucial, and its disruption may impact reproductive efficiency (Chou \& Chen 2018). These data therefore suggest that both BPA and BPS may affect oocyte competence through an impairment in GC oestradiol and progesterone secretion.

Our data suggested that BPA and BPS exerted a similar effect on ovine GC steroidogenesis. Interestingly, BPS altered the secretion of progesterone at a ten-fold lower concentration than BPA. Thus, regarding steroidogenesis, BPS does not seem to be a safe alternative to BPA. Additionally, compared to the literature, the ewe model used here appears to be more sensitive to BPS compared to other species. Even if all studies reported alterations in hormone secretions, there are discrepancies among studies and species. These differences may be partially related to species differences, follicular stage of GC recovery, treatment durations, doses and/or culture media composition (serum-free or not). Finally, BPA and BPS affected steroidogenesis at concentrations that are supraenvironmental compared with human female body fluid levels (nanomolar range). However, in this study, cells are exposed to high doses of bisphenols for only $48 \mathrm{~h}$, corresponding to an acute exposure. Of note, effects observed after acute high supraenvironmental doses might not reflect low chronic exposure consequences, which correspond to human exposure. Further experiments are therefore required to investigate impacts of chronic low exposure.

\section{$B P A$, but not BPS, impaired ovine GC viability and proliferation}

We showed that only the highest BPA concentration $(200 \mu \mathrm{M})$ induced a significant increase in cell mortality. No toxicity was evidenced with BPS, even at high concentrations. Lower concentrations of both BPA and BPS (up to $100 \mu \mathrm{M}$ ) did not exhibit any effect on ovine GC cellular viability. This result is consistent with previous studies on luteinised human GC (PogrmicMajkic et al. 2019), rat GC (Samardzija et al. 2018) and bovine GC (Campen et al. 2018).

We also reported a significant decrease in ovine GC proliferation after $50 \mu \mathrm{M}, 100 \mu \mathrm{M}$ or $200 \mu \mathrm{M}$ BPA treatment, while there was an effect only after $200 \mu \mathrm{M}$ BPS treatment. Differences among studies and species have been reported. Indeed, in human luteinised cells, up to $44 \mu \mathrm{M}$ BPA does not impact proliferation (Dominguez et al. 2008), whereas in porcine GC there is a decrease in proliferation after $10 \mu \mathrm{M}$ BPS treatment (Berni et al. 2019). During folliculogenesis, GC exhibit increased mitotic activity and secreted hormones, both of which are crucial for the growth and maturation of oocytes (Monniaux et al. 2019). The data obtained here may suggest that, considering cellular proliferation alone, BPS is not as detrimental as BPA. 


\section{BPA and BPS effects may be mediated through different mechanisms of action}

Regarding steroidogenic enzymes, we showed a decrease in the gene expression of CYP11A1 and HSD3B1 after $100 \mu \mathrm{M}$ BPA treatment. Both enzymes are involved in progesterone synthesis in GC. This result is consistent with previous studies in human and porcine GC (Mansur et al. 2016, Bujnakova Mlynarcikova et al. 2018) and with the decrease in progesterone secretion reported for this concentration in the present study. Ten micromolar BPA did not affect CYP11A1 and HSD3B1 protein and mRNA expression. It would be interesting to assess these protein expressions at the concentrations that affected gene expression (namely $100 \mu \mathrm{M}$ BPA). BPA did not affect the protein or gene expression of the enzyme CYP19A1, which is involved in oestradiol synthesis. HSD17B is also involved in oestradiol synthesis, and it would be interesting to investigate its expression. STAR gene expression was not modified after BPA treatment, and data are consistent with results in luteinised human GC (Mansur et al. 2016). BPS did not modulate protein or gene expression of any steroidogenic enzymes, while a decrease in progesterone and an increase in oestradiol is reported. This result is consistent with previous in vivo experiment in mice, where no difference in mRNA expression of steroidogenic enzymes was reported after injections of $50 \mu \mathrm{g} / \mathrm{kg}$ BPS (Shi et al. 2017). However, in addition to assessing steroidogenic enzyme expression, it would be interesting to measure their activities, as change in their activities could contribute to hormonal imbalance. Thus, BPA and BPS do not appear to act through similar pathways on steroidogenesis. Because our results in terms of mechanisms of action do not reconcile with the modifications of steroidogenesis observed in terms of both progesterone and oestradiol secretion, we could speculate that only the secretion and not the synthesis of these steroids might be affected. Further studies are needed to elucidate the detailed mechanisms of action.

We also investigated hormonal receptor expressions. Both ESR 1 and ESR2 expression were decreased by BPA and increased by BPS. These contradictory effects may be related to a difference in affinity towards oestrogen receptors. $P R$ gene expression was increased after $10 \mu \mathrm{M}$ and $50 \mu \mathrm{M}$ BPS treatment compared with the same BPA concentrations. At these concentrations, BPS (but not BPA) decreased progesterone secretion. Further studies are required to elucidate how BPA and BPS impaired progesterone secretion. The increase in $P R$ expression may therefore be a compensatory consequence of the decrease in progesterone secretion (Duffy \& Stouffer 1995). Finally, BPA decreased $A R$ gene expression. This result is consistent with the BPA-induced inhibition of proliferation. Indeed, there is a positive correlation between $A R$ gene expression in GC and proliferation (Chou \& Chen 2018).
Concerning signalling pathways, BPA induced less MAPK3/1 phosphorylation compared to the control. This phenomenon was not the same with BPS treatment. In addition to the already described mechanisms that involve binding to oestrogen receptors, new mechanisms emerged that should be investigated to elucidate the BPA and BPS mechanisms of action. Indeed, in HEK293T cells, both bisphenols can associate with a Ras protein, $\mathrm{K}$-Ras4B; the affinity of BPA is much higher compared to BPS (Schopel et al. 2016). Ras functions as a molecular switch that leads to the activation of signalling cascade, such as MAPK3/1 or AKT phosphorylation (Schopel et al. 2018). Differences between the BPA and BPS affinity towards Ras protein may help explain the difference in signalling pathway activation observed in the present study. Both BPA and BPS increased phosphorylation of AMPK $\alpha$ compared to control. The AMPK $\alpha$ signalling pathway is involved in energy metabolism and, in particular, the metabolism of cholesterol, which is a precursor for steroid production (Scaramuzzi et al. 2010). In addition to the study of cholesterol transport, assessed in this study through STAR gene expression, it would be interesting to measure cholesterol production in GC. Furthermore, a study in rat GC showed that BPA exposure alters cholesterol homeostasis - rendering it inaccessible to mitochondria - and thus decreases progesterone production (Samardzija et al. 2018). The disparities between BPA and BPS on gene expression and signalling pathway activation may suggest that BPA and BPS do not share all their mechanisms of action.

Several limitations occurred in this study, related to the use of ovine ovaries collected in slaughterhouse. Indeed, health and metabolic status of ewes are unknown. Culture of GC was performed in atmospheric air humidified with $5 \% \mathrm{CO}_{2}$ and $20 \% \mathrm{O}_{2}$. This excess of $\mathrm{O}_{2}$ is not physiological (Thompson et al. 2015) and could have potential consequences on cellular functions (i.e. production of reactive oxygen species) (Stuart et al. 2018). Also, McCoy medium used for culture contained phenol red which has oestrogenic properties and might not be ideal to evaluate endocrine disrupting properties of compounds such as bisphenols (similar effects on GC progesterone secretion were observed in phenol red free and phenol red containing medium, Supplementary Fig. 3). Nevertheless, the medium used also contained oestradiol, because GC are oestradiol-producing cells. As oestradiol has stronger oestrogenic properties, it renders negligible the oestrogenic effect of phenol red. The effects of BPA and BPS are therefore studied in oestrogenic environment, corresponding to physiological conditions. Here, we described the acute effects (48-h culture) of BPA and BPS on GC steroidogenesis in adult ewe. A large range of BPA and BPS doses were evaluated, ranging from environmental ( $1 \mathrm{nM}$ to $100 \mathrm{nM}$ ) to supraenvironmental concentrations $(1 \mu \mathrm{M}$ to $200 \mu \mathrm{M})$. We showed here that BPA and BPS reduced progesterone secretion and 
increased oestradiol secretion. These data suggested that BPS might not be a safe alternative for BPA, which could have a high relevance for human health and reproduction. Nevertheless, our findings are related to supraenvironmental concentrations.

\section{Conclusions}

The present study compared the effects of BPA and BPS on ovine GC. We demonstrated that BPA and BPS altered steroidogenesis by increasing oestradiol secretion and reducing progesterone secretion. BPS was even more detrimental to progesterone secretion compared to BPA because it induced a reduction at a concentration ten-fold lower than BPA. On the contrary, BPA reduced cell proliferation at a lower concentration compared with BPS. Our results on gene expression and signalling pathways suggest that the mechanisms of action involved by which BPA and BPS exert their effects on GC may not be completely similar. Taken together, BPS does not appear to be a safe alternative to BPA. Further investigations are needed to elucidate the BPA and BPS mechanisms of action involved in ovine GC steroidogenesis alterations.

\section{Supplementary materials}

This is linked to the online version of the paper at https://doi. org/10.1530/REP-19-0575.

\section{Declaration of interest}

The authors declare that there is no conflict of interest that could be perceived as prejudicing the impartiality of the reported research.

\section{Funding}

This work was financially supported by the INRAE, 'CentreVal de Loire' Region (Bemol project, APR IR 2017), the French National Research Agency (project ANR-18-CE34-0011-01 MAMBO) and the BioMedecine Agency (Project 18AMP006 FertiPhenol).

\section{Author contribution statement}

$\mathrm{O} \mathrm{T}$ and $\mathrm{M} J$ performed experiments, analysed the data and wrote the paper. A D and P P performed experiments. A B and $\checkmark \mathrm{M}$ helped write the paper. S E conceived the study, performed experiments, analysed the data and wrote the paper.

\section{Acknowledgements}

The authors would like to thank Albert Arnould and Thierry Delpuech for ovine ovary collection and the Endocrinology and Phenotyping Laboratory (Reproductive Physiology and
Behaviours Unit, INRAE Nouzilly) and Dominique Gennetay for progesterone assay.

\section{References}

Banerjee O, Singh S, Prasad SK, Bhattacharjee A, Banerjee A, Banerjee A, Saha A, Maji BK \& Mukherjee S 2018 Inhibition of catalase activity with 3-amino-1,2,4-triazole intensifies bisphenol A (BPA)-induced toxicity in granulosa cells of female albino rats. Toxicology and Industrial Health $\mathbf{3 4}$ 787-797. (https://doi.org/10.1177/0748233718795744)

Berni M, Gigante P, Bussolati S, Grasselli F, Grolli S, Ramoni R \& Basini G 2019 Bisphenol S, a bisphenol A alternative, impairs swine ovarian and adipose cell functions. Domestic Animal Endocrinology 66 48-56. (https://doi.org/10.1016/j.domaniend.2018.08.001)

Bloom MS, Mok-Lin E \& Fujimoto VY 2016 Bisphenol A and ovarian steroidogenesis. Fertility and Sterility $\mathbf{1 0 6} 857-863$. (https://doi. org/10.1016/j.fertnstert.2016.08.021)

Bujnakova Mlynarcikova A \& Scsukova S 2018 Simultaneous effects of endocrine disruptor bisphenol $\mathrm{A}$ and flavonoid fisetin on progesterone production by granulosa cells. Environmental Toxicology and Pharmacology 59 66-73. (https://doi.org/10.1016/j.etap.2018.03.001)

Campen KA, Lavallee M \& Combelles C 2018 The impact of bisphenol S on bovine granulosa and theca cells. Reproduction in Domestic Animals $\mathbf{5 3}$ 450-457. (https://doi.org/10.1111/rda.13130)

Canépa S, Lainé A, Bluteau A, Fagu C, Flon C \& Monniaux D 2008 Validation d'une méthode immunoenzymatique pour le dosage de la progestérone dans le plasma des ovins et des bovins. Cahiers Techniques de I'INRA 64 19-30.

Chen D, Kannan K, Tan H, Zheng Z, Feng YL, Wu Y \& Widelka M 2016 Bisphenol analogues other than BPA: environmental occurrence, human exposure, and toxicity: a review. Environmental Science and Technology 50 5438-5453. (https://doi.org/10.1021/acs.est.5b05387)

Chou CH \& Chen MJ 2018 The effect of steroid hormones on ovarian follicle development. Vitamins and Hormones 107 155-175. (https:// doi.org/10.1016/bs.vh.2018.01.013)

Corbel T, Gayrard V, Viguie C, Puel S, Lacroix MZ, Toutain PL \& Picard-Hagen N 2013 Bisphenol A disposition in the sheep maternalplacental-fetal unit: mechanisms determining fetal internal exposure. Biology of Reproduction 89 11. (https://doi.org/10.1095/biolreprod. 112.106369)

Dominguez MA, Petre MA, Neal MS \& Foster WG 2008 Bisphenol A concentration-dependently increases human granulosa-lutein cell matrix metalloproteinase-9 (MMP-9) enzyme output. Reproductive Toxicology 25 420-425. (https://doi.org/10.1016/j.reprotox.2008.05.059)

Duffy DM \& Stouffer RL 1995 Progesterone receptor messenger ribonucleic acid in the primate corpus luteum during the menstrual cycle possible regulation by progesterone. Endocrinology 136 1869-1876. (https://doi. org/10.1210/endo.136.5.7720632)

Eladak S, Grisin T, Moison D, Guerquin MJ, N'tumba-byn T, PozziGaudin S, Benachi A, Livera G, Rouiller-Fabre V \& Habert R 2015 A new chapter in the bisphenol A story: bisphenol $\mathrm{S}$ and bisphenol $\mathrm{F}$ are not safe alternatives to this compound. Fertility and Sterility 103 11-21. (https://doi.org/10.1016/j.fertnstert.2014.11.005)

European-Food-Safety-Authority 2015 Scientific Opinion on the risks to public health related to the presence of bisphenol A (BPA) in foodstuffs. EFSA Journal 13 3978. (https://doi.org/10.2903/j.efsa.2015.3978)

Fan HY, Liu Z, Shimada M, Sterneck E, Johnson PF, Hedrick SM \& Richards JS 2009 MAPK3-1 (ERK1-2) in ovarian granulosa cells are essential for female fertility. Science 324 938-941. (https://doi. org/10.1126/science.1171396)

Gingrich J, Pu Y, Ehrhardt R, Karthikraj R, Kannan K \& Veiga-Lopez A 2019 Toxicokinetics of bisphenol A, bisphenol S, and bisphenol $F$ in a pregnancy sheep model. Chemosphere 220 185-194. (https://doi. org/10.1016/j.chemosphere.2018.12.109)

Grandin FC, Lacroix MZ, Gayrard V, Gauderat G, Mila H, Toutain PL \& Picard-Hagen N 2018 Bisphenol S instead of bisphenol A: toxicokinetic investigations in the ovine materno-feto-placental unit. Environment International 120 584-592. (https://doi.org/10.1016/j. envint.2018.08.019)

Grasselli F, Baratta L, Baioni L, Bussolati S, Ramoni R, Grolli S \& Basini G 2010 Bisphenol A disrupts granulosa cell function. 
Domestic Animal Endocrinology 39 34-39. (https://doi.org/10.1016/j. domaniend.2010.01.004)

Grignard E, Lapenna S \& Bremer S 2012 Weak estrogenic transcriptional activities of bisphenol A and bisphenol S. Toxicology In Vitro 26 727-731. (https://doi.org/10.1016/j.tiv.2012.03.013)

Hernandez-Medrano JH, Campbell BK \& Webb R 2012 Nutritional influences on folliculogenesis. Reproduction in Domestic Animals 47 (Supplement 4) 274-282. (https://doi.org/10.1111/j.14390531.2012.02086.x)

Hines CJ, Jackson MV, Deddens JA, Clark JC, Ye X, Christianson AL, Meadows JW \& Calafat AM 2017 Urinary bisphenol A (BPA) concentrations among workers in industries that manufacture and use BPA in the USA. Annals of Work Exposures and Health 61 164-182. (https://doi.org/10.1093/annweh/wxw021)

Lapointe E \& Boerboom D 2011 WNT signaling and the regulation of ovarian steroidogenesis. Frontiers in Bioscience 3 276-285. (https://doi. org/10.2741/s151)

Lunardi FO, Bass CS, Bernuci MP, Chaves RN, Lima LF, Silva RF, Figueiredo JR \& Rodrigues AP 2015 Ewe ovarian tissue vitrification: a model for the study of fertility preservation in women. JBRA Assisted Reproduction 19 241-251. (https://doi.org/10.5935/1518-0557.20150047)

Ma Y, Liu H, Wu J, Yuan L, Wang Y, Du X, Wang R, Marwa PW, Petlulu P, Chen X et al. 2019 The adverse health effects of bisphenol A and related toxicity mechanisms. Environmental Research 176 108575. (https://doi. org/10.1016/j.envres.2019.108575)

Maillard V, Desmarchais A, Durcin M, Uzbekova S \& Elis S 2018 Docosahexaenoic acid (DHA) effects on proliferation and steroidogenesis of bovine granulosa cells. Reproductive Biology and Endocrinology 16 40. (https://doi.org/10.1186/s12958-018-0357-7)

Mansur A, Adir M, Yerushalmi G, Hourvitz A, Gitman H, Yung Y, Orvieto R \& Machtinger R 2016 Does BPA alter steroid hormone synthesis in human granulosa cells in vitro? Human Reproduction 31 1562-1569. (https://doi.org/10.1093/humrep/dew088)

Mlynarcikova A, Kolena J, Fickova M \& Scsukova S 2005 Alterations in steroid hormone production by porcine ovarian granulosa cells caused by bisphenol A and bisphenol A dimethacrylate. Molecular and Cellular Endocrinology 244 57-62. (https://doi.org/10.1016/j.mce.2005.02.009)

Molina-Molina JM, Amaya E, Grimaldi M, Saenz JM, Real M, Fernandez MF, Balaguer P \& Olea N 2013 In vitro study on the agonistic and antagonistic activities of bisphenol-S and other bisphenol-A congeners and derivatives via nuclear receptors. Toxicology and Applied Pharmacology 272 127-136. (https://doi.org/10.1016/j.taap.2013.05.015)

Monniaux D, Clement F, Dalbies-Tran R, Estienne A, Fabre S, Mansanet C \& Monget P 2014 The ovarian reserve of primordial follicles and the dynamic reserve of antral growing follicles: what is the link? Biology of Reproduction 90 85. (https://doi.org/10.1095/biolreprod.113.117077)

Monniaux D, Cadoret V, Clément F, Dalbies-Tran R, Elis S, Fabre S, Maillard V, Monget P \& Uzbekova S 2019 Folliculogenesis. In Encyclopedia of Endocrine Diseases. Elsevier Science. (https://doi. org/10.1016/B978-0-12-801238-3.64550-6)

Peter AT \& Dhanasekaran N 2003 Apoptosis of granulosa cells a review on the role of MAPK-signalling modules. Reproduction in Domestic Animals 38 209-213. (https://doi.org/10.1046/j.1439-0531.2003.00438.x)

Pogrmic-Majkic K, Samardzija Nenadov D, Fa S, Stanic B, Trninic Pjevic A \& Andric N 2019 BPA activates EGFR and ERK1/2 through PPARgamma to increase expression of steroidogenic acute regulatory protein in human cumulus granulosa cells. Chemosphere 229 60-67. (https://doi. org/10.1016/j.chemosphere.2019.04.174)

Rivera OE, Varayoud J, Rodriguez HA, Munoz-De-toro M \& luque EH 2011 Neonatal exposure to bisphenol A or diethylstilbestrol alters the ovarian follicular dynamics in the lamb. Reproductive Toxicology 32 304-312. (https://doi.org/10.1016/j.reprotox.2011.06.118)

Samardzija D, Pogrmic-Majkic K, Fa S, Stanic B, Jasnic J \& Andric N 2018 Bisphenol A decreases progesterone synthesis by disrupting cholesterol homeostasis in rat granulosa cells. Molecular and Cellular Endocrinology 461 55-63. (https://doi.org/10.1016/j.mce.2017.08.013)

Scaramuzzi RJ, Brown HM \& Dupont J 2010 Nutritional and metabolic mechanisms in the ovary and their role in mediating the effects of diet on folliculogenesis: a perspective. Reproduction in Domestic Animals 45 (Supplement 3) 32-41. (https://doi.org/10.1111/j.14390531.2010.01662.x)

Scaramuzzi RJ, Baird DT, Campbell BK, Driancourt MA, Dupont J, Fortune JE, Gilchrist RB, Martin GB, McNatty KP, McNeilly AS et al. 2011. Regulation of folliculogenesis and the determination of ovulation rate in ruminants. Reproduction, Fertility and Development 23 444-467. (https://doi.org/10.1071/RD09161)

Schopel M, Herrmann C, Scherkenbeck J \& Stoll R 2016 The bisphenol A analogue bisphenol S binds to K-Ras4B - implications for 'BPA-free' plastics. FEBS Letters 590 369-375. (https://doi.org/10.1002/18733468.12056)

Schopel M, Shkura O, Seidel J, Kock K, Zhong X, Loffek S, Helfrich I, Bachmann HS, Scherkenbeck J, Herrmann C et al. 2018 Allosteric activation of GDP-bound Ras isoforms by bisphenol derivative plasticisers. International Journal of Molecular Sciences 19 E1133. (https://doi.org/10.3390/ijms19041133)

Shi M, Sekulovski N, Maclean 2nd JA \& Hayashi K 2017 Effects of bisphenol A analogues on reproductive functions in mice. Reproductive Toxicology 73 280-291. (https://doi.org/10.1016/j.reprotox.2017.06.134)

Song D, Wu G, Wei Q \& Shi F 2019 Bisphenol A attenuates thyroxineinduced apoptosis in ovarian granulosa cells of pigs. Reproduction in Domestic Animals 54 864-872. (https://doi.org/10.1111/rda.13436)

Souter I, Smith KW, Dimitriadis I, Ehrlich S, Williams PL, Calafat AM \& Hauser R 2013 The association of bisphenol-A urinary concentrations with antral follicle counts and other measures of ovarian reserve in women undergoing infertility treatments. Reproductive Toxicology 42 224-231. (https://doi.org/10.1016/j.reprotox.2013.09.008)

Stuart JA, Fonseca J, Moradi F, Cunningham C, Seliman B, Worsfold CR, Dolan S, Abando J \& Maddalena LA 2018 How supraphysiological oxygen levels in standard cell culture affect oxygen-consuming reactions. Oxidative Medicine and Cellular Longevity 2018 8238459. (https://doi. org/10.1155/2018/8238459)

Thompson JG, Brown HM, Kind KL \& Russell DL 2015 The ovarian antral follicle: living on the edge of hypoxia or not?. Biology of Reproduction 92 153. (https://doi.org/10.1095/biolreprod.115.128660)

Tomza-Marciniak A, Stepkowska P, Kuba J \& Pilarczyk B 2018 Effect of bisphenol A on reproductive processes: a review of in vitro, in vivo and epidemiological studies. Journal of Applied Toxicology 38 51-80. (https://doi.org/10.1002/jat.3480)

Usman A \& Ahmad M 2016 From BPA to its analogues: is it a safe journey? Chemosphere 158 131-142. (https://doi.org/10.1016/j. chemosphere.2016.05.070)

Vandenberg LN, Hauser R, Marcus M, Olea N \& Welshons WV 2007 Human exposure to bisphenol A (BPA). Reproductive Toxicology 24 139-177. (https://doi.org/10.1016/j.reprotox.2007.07.010)

Wu G, Song D, Wei Q, Xing J, Shi X \& Shi F 2018a Melatonin mitigates bisphenol A-induced estradiol production and proliferation by porcine ovarian granulosa cells in vitro. Animal Reproduction Science 192 91-98. (https://doi.org/10.1016/j.anireprosci.2018.02.018)

Wu LH, Zhang XM, Wang F, Gao CJ, Chen D, Palumbo JR, Guo Y \& Zeng EY $2018 b$ Occurrence of bisphenol $S$ in the environment and implications for human exposure: a short review. Science of the Total Environment 615 87-98. (https://doi.org/10.1016/j.scitotenv.2017.09.194)

Zhou W, Liu J, Liao L, Han S \& Liu J 2008 Effect of bisphenol A on steroid hormone production in rat ovarian theca-interstitial and granulosa cells. Molecular and Cellular Endocrinology 283 12-18. (https://doi. org/10.1016/j.mce.2007.10.010)

Received 29 November 2019

First decision 13 January 2020

Revised manuscript received 10 February 2020

Accepted 24 February 2020 